\title{
NMR and Mass Spectroscopic Studies on Catharine
}

Atta-ur-Rahman*, Irshad Ali, and M. Iqbal Chaudhary

H. E. J. Research Institute of Chemistry, University of Karachi, Karachi-32/Pakistan

Z. Naturforsch. 40b, 543-545 (1985); received August 20/December 20, 1984

Catharine, Conformational Analysis, ${ }^{13} \mathrm{C}$ NMR

The ${ }^{13} \mathrm{C}$ NMR of catharine is reported. A temperature-dependent study of the ${ }^{1} \mathrm{H}$ NMR of catharine indicates that it exists as two conformers at room temperature. At higher temperatures, the distinction between the two conformers disappears with the higher rate of equilibration. The mass spectral fragmentation of catharine as established by link scan measurements is also reported.

Catharanthus roseus L. G. Don (Apocynaceae) is a commonly grown plant of Pakistan. A number of indole and bisindole alkaloids have been previously reported from this plant, one of them being catharine $[1,2]$.

The ${ }^{13} \mathrm{C}$ NMR spectrum $(25 \mathrm{MHz})$ of catharine afforded 46 signals. The assignments (Table I) were made by comparison with the ${ }^{13} \mathrm{C}$ NMR spectra of other binary indole alkaloids [3-5] and substantiated by using gated spin echo measurements. In addition to the expected signals, an interesting doubling of a number of peaks (e.g. $\delta 51.40 / 51.59,173.01 / 173.55$ and 202.47/204.26) was observed. Since the compound in hand was pure, it was suspected that

Table I. ${ }^{13} \mathrm{C}$ NMR of Catharine.

\begin{tabular}{lrlr}
\hline Carbon No. & $\begin{array}{l}\text { Chemical } \\
\text { shift }\end{array}$ & Carbon No. & $\begin{array}{l}\text { Chemical } \\
\text { shift }\end{array}$ \\
\hline 2 & 83.41 & $2^{\prime}$ & 134.46 \\
3 & 50.85 & $3^{\prime}$ & 162.08 \\
5 & 50.32 & $4^{\prime}$ & 204.26 \\
6 & 50.32 & $5^{\prime}$ & 56.32 \\
7 & 44.46 & $6^{\prime}$ & 27.95 \\
8 & 124.13 & $7^{\prime}$ & 117.81 \\
9 & 122.83 & $8^{\prime}$ & 127.89 \\
10 & 121.11 & $9^{\prime}$ & 118.41 \\
11 & 159.32 & $10^{\prime}$ & 121.27 \\
12 & 94.92 & $11^{\prime}$ & 118.67 \\
13 & 153.23 & $12^{\prime}$ & 111.35 \\
14 & 124.46 & $13^{\prime}$ & 134.05 \\
15 & 130.19 & $15^{\prime}$ & 51.40 \\
16 & 79.65 & $16^{\prime}$ & 52.41 \\
17 & 70.32 & $17^{\prime}$ & 31.13 \\
18 & 8.21 & $18^{\prime}$ & 11.17 \\
19 & 30.71 & $19^{\prime}$ & 29.04 \\
20 & 42.95 & $20^{\prime}$ & 95.18 \\
21 & 66.58 & $21^{\prime}$ & 126.56 \\
$-\mathrm{CO}_{2} \mathrm{CH}_{3}$ & 170.74 & $-\mathrm{C}^{\prime} \mathrm{O}_{2} \mathrm{CH}_{3}$ & 173.55 \\
$-\mathrm{CO}_{2} \mathrm{CH}_{3}$ & 52.21 & $-\mathrm{C}^{\prime} \mathrm{O}_{2} \mathrm{CH}_{3}$ & 52.06 \\
\hline
\end{tabular}

* Reprint requests to Prof. Dr. Atta-ur-Rahman. Verlag der Zeitschrift für Naturforschung, D-7400 Tübingen 0340-5087/85/0400-0543/\$ 01.00/0 catharine existed in a mobile equilibrium between two conformers. A similar phenomenon was observed in the PMR spectrum of catharine in which a doubling of peaks was seen to occur at $\delta 2.21 / 2.25,5.02 / 5.10,5.41 /$ 5.45 and 7.64/8.14. The PMR spectrum was therefore recorded at increasing temperatures $\left(22^{\circ} \mathrm{C}, 30^{\circ} \mathrm{C}\right.$, $40{ }^{\circ} \mathrm{C}, 45^{\circ} \mathrm{C}, 55^{\circ} \mathrm{C}$ and $60{ }^{\circ} \mathrm{C}$ ). At $50^{\circ} \mathrm{C}$, the doublets began to collapse to single peaks and at $60^{\circ} \mathrm{C}$ sharp singlets appeared at the midpoints of the previous doublets. A study of the Dreiding models of catharine shows that while the eleven membered nitrogen-containing ring in the indole moiety is very flexible, catharine may convievably exist in two con-

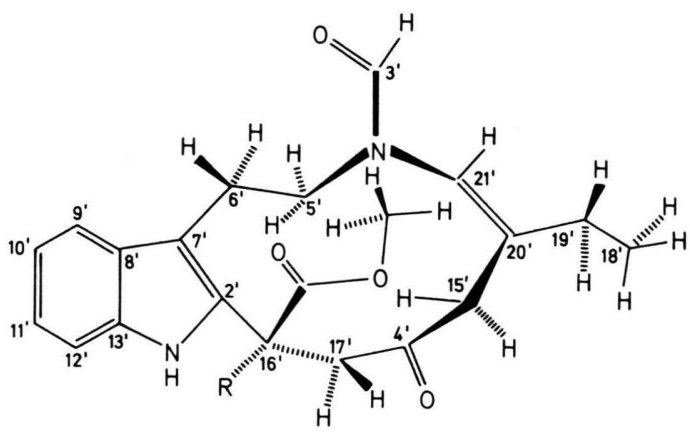

$$
R=10-\text { VINDOLINYL } \quad 1
$$

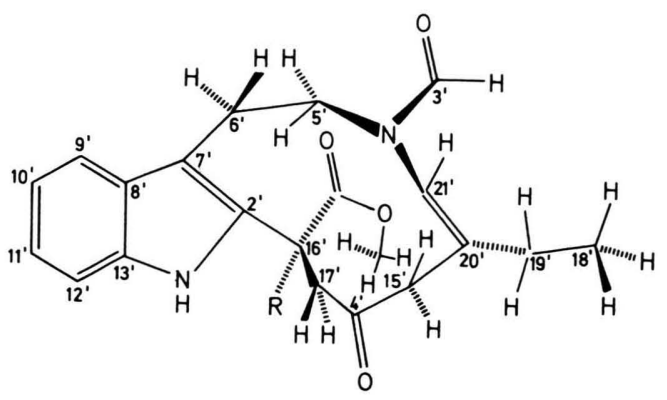

$R=10-$ VINDOLINYL 
formers (1) and (2) at room temperature. This appears to be due to several steric interactions experienced on conversion of one conformer to the other. Dreiding models indicate that it is possible to twist the ester group at C-16' through the eleven-membered nitrogen containing ring so that it comes to lie on the other side. However, it is seen to experience some steric hinderances with a number of atoms on going from one conformation to the other. Some important interactions which can be seen are between $6^{\prime} \alpha-\mathrm{H}$ and $15^{\prime} \alpha-\mathrm{H}, 6^{\prime}-\beta \mathrm{H}$, and $15^{\prime} \beta \mathrm{H}, 17^{\prime} \alpha \mathrm{H}$ and $5^{\prime} \alpha \mathrm{H}, 5^{\prime} \beta \mathrm{H}$ and $17^{\prime} \alpha \mathrm{H}, 5^{\prime} \mathrm{H}$ and $-\mathrm{CO}_{2} \mathrm{CH}_{3}$ group, $\mathrm{N}-\mathrm{CHO}$ group and $\mathrm{CO}_{2} \mathrm{Me}$ group, $21^{\prime} \mathrm{H}$ and $-\mathrm{CO}_{2} \mathrm{CH}_{3}$ group, and $20^{\prime} \mathrm{C}$ and $\mathrm{CO}_{2} \mathrm{CH}_{3}$ group. These interactions appear to create a sufficiently large energy barrier between the two conformations so as to allow them to exist in two distinguishable states.

A study of the fragmentation pathway of catharine by linked scan measurements (Scheme I, II) showed that the molecular ion at $\mathrm{m} / z 822$ fragments directly to the ions at $\mathrm{m} / z 763$ and 662 . Computer monitored

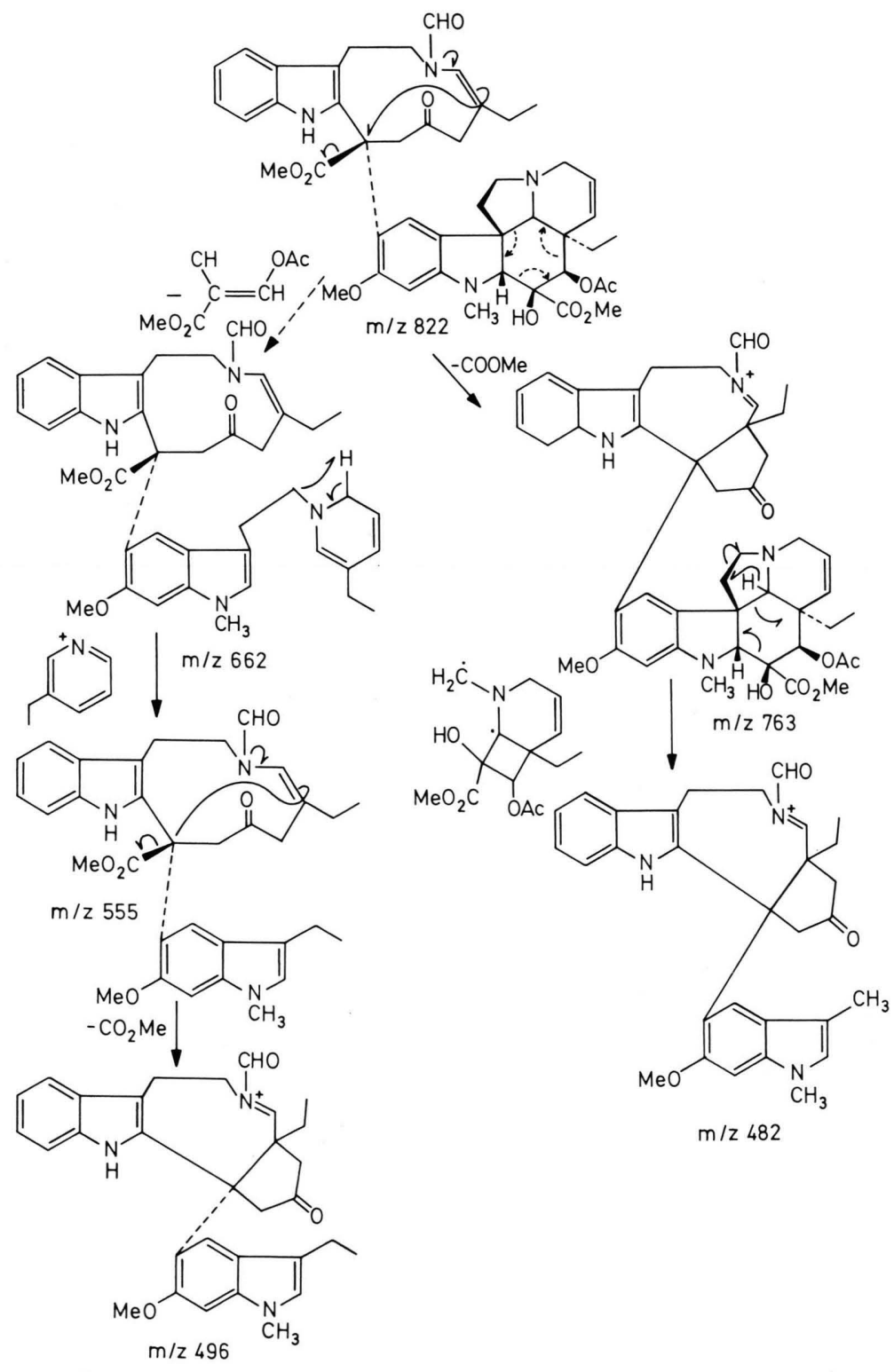


high resolution mass measurements of these and other important ions afforded the masses 822.3816 (calcd for $\mathrm{C}_{46} \mathrm{H}_{54} \mathrm{~N}_{4} \mathrm{O}_{10}, 822.3822$ ), 763.3692 (calcd for $\mathrm{C}_{44} \mathrm{H}_{51} \mathrm{~N}_{4} \mathrm{O}_{8}, 763.3707$ ), 662.3448 (calcd for $\mathrm{C}_{40} \mathrm{H}_{46} \mathrm{~N}_{4} \mathrm{O}_{5}, \quad 622.3468$ ), 555.2717 (calcd for $\mathrm{C}_{33} \mathrm{H}_{37} \mathrm{~N}_{3} \mathrm{O}_{5}$, 555.2721), 496.2591 (calcd for
$\mathrm{C}_{31} \mathrm{H}_{31} \mathrm{~N}_{3} \mathrm{O}_{3}, \quad 496.2589$ ), 482.2564 (calcd for $\mathrm{C}_{30} \mathrm{H}_{32} \mathrm{~N}_{3} \mathrm{O}_{3}, 482.2566$ ), 411.1920 (calcd for $\mathrm{C}_{46} \mathrm{H}_{54} \mathrm{~N}_{4} \mathrm{O}_{10}, 411.1911$ ), 367.1691 (calcd for $\mathrm{C}_{21} \mathrm{H}_{23} \mathrm{~N}_{2} \mathrm{O}_{4}, \quad 367.1657$ ), 282.1328 (calcd for $\mathrm{C}_{14} \mathrm{H}_{20} \mathrm{NO}_{5}, 282.1341$ ), 135.1037 (calcd for $\mathrm{C}_{9} \mathrm{H}_{13} \mathrm{~N}$, 135.1048), 107.0721 (calcd for $\mathrm{C}_{7} \mathrm{H}_{9} \mathrm{~N}, 107.0734$ ).

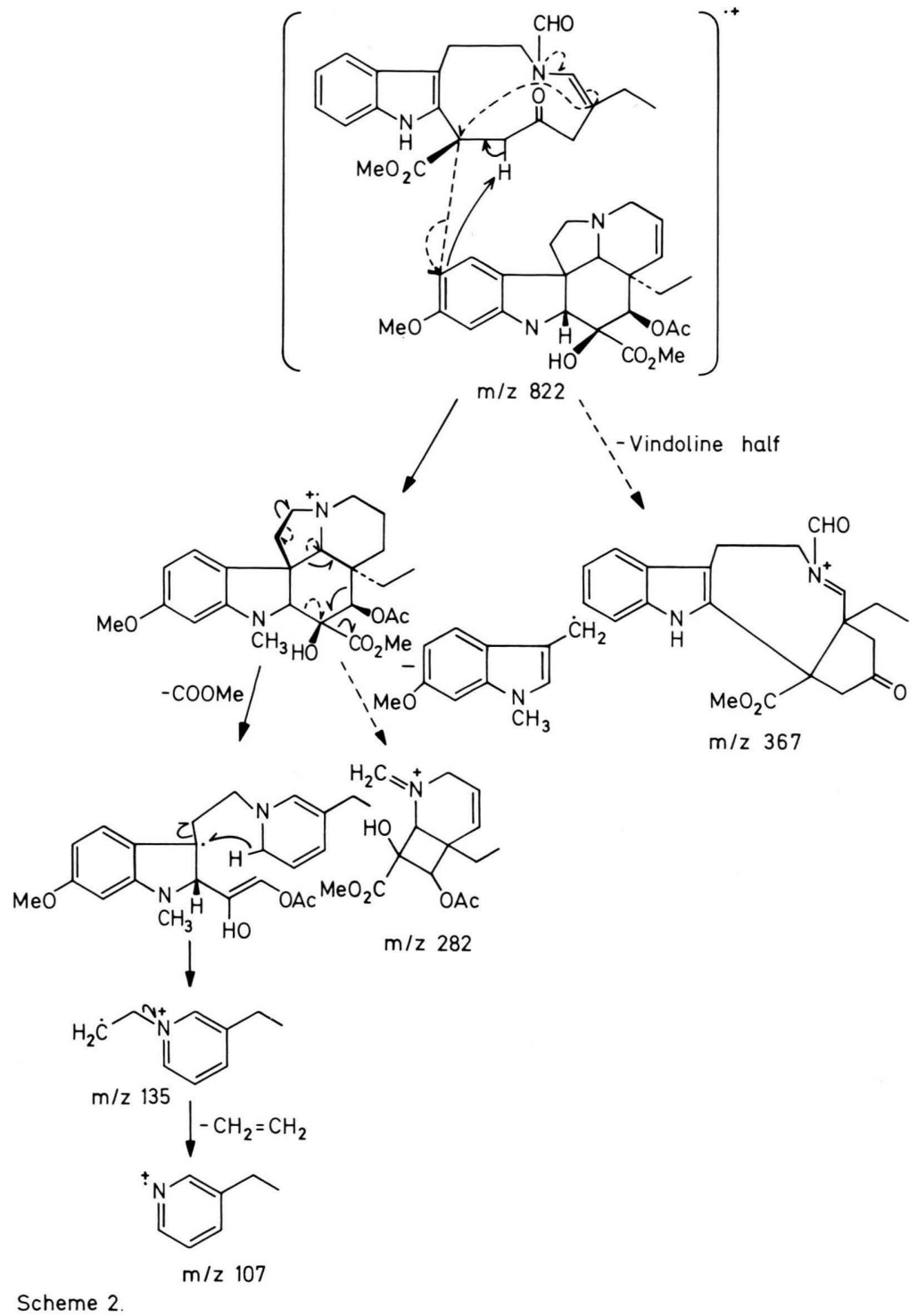

[1] G. H. Svoboda, M. Gorman, N. Neuss, and A. J. Barnes, J. Pharm. Sci. 50, 409 (1961).

[2] J. P. Kutney, J. Balsevich, and B. R. Worth, Heterocycles 9, 493 (1978).

[3] D. E. Dorman and J. W. Paschal, Org. Magn. Reson. 8, 413 (1976).
[4] E. Wenkert, E. W. Hagaman, B. Lal, G. E. Gutowski, A. S. Katuer, J. C. Miller, and N. Neuss, Helv. Chim. Acta 58, 1560 (1975).

[5] S. S. Tafur, J. L. Occolowitz, T. K. Elzey, J. W. Paschal, and D. E. Dorman, J. Org. Chem. 41, 1001 (1976).

[6] "The Alkaloids", Vol. XX, R. H. F. Manske, R. G. A. Rodrig, p. 194-195, Academic Press, New York 1981. 